\title{
MONTE-CARLO SZIMULÁCIÓVAL TÁMOGATOTT ÜZLETI FOLYAMATFEJLESZTÉS
}

\section{Szerzők:}

Kósa Dóra

Debreceni Egyetem

Kósáné Estefán Zsuzsa

Debreceni Egyetem

Kocsi Balázs

Debreceni Egyetem

Első szerző e-mail címe:

kdorik98@gmail.com

\section{Lektorok:}

Mező Ferenc (PhD)

Eszterházy Károly Katolikus Egyetem

Mező Katalin (PhD)

Debreceni Egyetem

...és további két anonim lektor

\section{Absztrakt}

A tanulmány témája Monte-Carlo szimulációval támogatott üzleti folyamatfejlesztés egy könnyűfémcsomagoló eszközöket előállító vállalatnál.

Kulcsszavak: szimuláció, folyamatmenedzsment, átfutási idő, A3, P-FMEA, BPMN 2.0, Ishikawa

Diszciplina: műszaki tudomány

\begin{abstract}
BUSINESS PROCESS DEVELOPMENT WITH SUPPORTED BY MONTECARLO SIMULATION

The topic of this study is business process development supported by a Monte-Carlo simulation at a light metal packaging company.
\end{abstract}

Keywords: simulation, process management, lead time, A3, P-FMEA, BPMN 2.0, Ishikawa

Disciplines: technical science

Kósa Dóra, Kósáné Estefán Zsuzsa és Kocsi Balázs (2021): Monte-Carlo szimulációval támogatott üzleti folyamatfejlesztés. Mesterséges intelligencia - interdiszciplináris folyóirat, III. évf. 2021/2. szám. 97-104. doi: 10.35406/MI.2021.2.97 
E kézirat témája a Monte-Carlo szimulációval támogatott üzleti folyamatfejlesztés egy könnyúfémcsomagoló eszközöket előállitó vállalatnál. A kutatás során alkalmazott üzleti folyamatmenedzsment célja, hogy a folyamatainkat átlátva, az értékek áramlásának optimalizálásával minél magasabb szinten tudjunk megfelelni vevőink elvárásainak. A fejlesztések megvalósításához szükséges folyamatés minőségfejlesztő technikák segítségével meghatározott javítóintézkedések hatását szimuláció segítségével vizsgálhatjuk, így a valóságon alapuló modell könnyebben áttekinthetô és értelmezhető lesz. Abban az esetben, ha a bemenó adataink bizonytalanok, esetleg véletlenszerűek, célszerű a modell szemléltetésére a Monte-Carlo szimulációt alkalmaznunk, melynek célja, hogy random értékekkel és eseményekkel szimuláljunk olyan problémát, amelynek alapadataiban bizonytalansági faktor merül fel.

A kutatás elsődleges célja, egy könnyűfémcsomagoló termékeket termelő üzem aktuális lakkozási folyamatának fejlesztése, a teljes átfutási idejének 50\%-kal való csökkentése, valamint a potenciális hibák számának csökkentése.

A hat területi szegmensben termelő cég vevői visszajelzéseinek Pareto-elemzése alapján került kijelölésre lakkozó üzemrészleg a kutatás területének. A továbbiakban a gembán, vagyis az értékteremtés helyén történő megfigyelések és információ gyűjtések alapján BPMN (Business Process Management Notation) 2.0 folyamatábrázolási módszer segítségével modellezzük a folyamatot, majd a Task Force Team munkacsoport bevonásával a lehetséges hibamódokat és okokat foglaljuk listába. A felsorolás alapján készül el a művelet P-FMEA (Process Failure Mode and Effect Analysis) elemzése, melynek kiértékelése során az RPN (Risk Priority Number) kockázati rangszám segítségével rangsoroljuk az adott hibákat. A legsúlyosabb hibák közül a team következő fókusza a lakkátkenődés problémája lesz, ezért kerül sor e hiba részletesebb elemzésére. A problémáról rendelkezésre álló január-május időszakra vonatkozó adatokat A3 jelentés segítségével foglaljuk össze. A jelentés részeként a gyökérokok feltárásához Ishikawa-diagram alkalmazására kerül sor, melynek segítségével meghatározhatók a szükséges javítóintézkedéseket.

Következő lépésként folyamatszimuláció segítségével vázoljuk fel a három lehetséges gyártási modellt. A Monte-Carlo szimuláció elméletét alkalmazva generált random számok segítségével határozzuk meg a teljes átfutási időt. A számtani eredményekre hivatkozva elmondható, hogy a meghatározott javítóintézkedések megvalósítása után, elérhető az a kitűzött cél, hogy a jelenlegi gyártási folyamat átfutási ideje 53\%-kal redukálható, valamint, hogy az átfutási idő arányában az aktuális hibafaktorok száma és súlya is csökkenthető.

A kutatás során implementált eljárás alkalmazható olyan fejlesztések és problémák megoldására, ahol az alapadatokban valamilyen bizonytalansági tényező merül fel. Segítségével modellezhetjük és elemezhetjük a várt jövőállapotot. A fejlesztéshez fontos, hogy reális adatokkal dolgozzunk, bevonjuk az érintett területen dolgozó kollégákat és egymás 
szakmaitudását és kreativitását kiegészítve hozzunk célravezető döntéseket.

\section{Háttér}

A kézirat tárgya a szimulációval támogatott üzleti folyamatfejlesztés egy piacvezető könynyúfémcsomagoló eszközöket előállító és értékesítő vállalat magyarországi telephelyű cégénél.

Az Ipar 4.0 napjaiban számos vállalat és vezetô még mindig csak ismerkedik a Lean, a Kaizen és egyéb termelést ösztönző szemléletek fogalmaival és technikáival, valamint az általuk ígért lehetőségekkel. Próbálnak felzárkózni a velük egy piacon lévő társaikhoz, egyfajta „trendként” tekintve az általuk alkalmazott technikákra. Ezen az úton az egyik mérföldkő, ha megértjük miért fontos arra törekednünk, hogy folyamatainkat minél magasabb szinten legyünk képesek menedzselni.

A menedzseri feladatokat a PDCA (Plan, Do, Check, Act) ciklus elméletének társításával célszerű elvégezni (Lodgaard, Gamme és Aasland, 2013), azaz: tervezni, elvégezni, ellenőrizni, beavatkozni, valamint fejleszteni szükséges ahhoz, hogy elhárítsuk azokat a gátakat, amelyek akadályoznak minket a fejlődésben, optimális megoldást találjunk a felmerülő hibák megszűntetésére, és stabil, megbízható folyamataink legyenek a minél magasabb eredménypotenciál elérésének érdekében. A megfelelő intézkedésekhez ismernünk kell a problémát és a hozzá kapcsolódó folyamatokat, valamint elôre kell vetítenünk és vizsgálnunk a várt állapotot. Ezen folyamat egyik megoldási lehetőségét taglalja e kutatás melyben a már említett vállalat egyik gyártási metódusa során felmerülő problémájának megszűntetése érdekében hozott javítóintézkedések előre jelzett hatását Monte-Carlo szimuláció segítségével vizsgáljuk.

Néhány háttérinformáció a tanulmányban használt kifejezésekkel kapcsolatban:

Folyamatfejlesztés. A folyamatfejlesztés egy olyan projekt, amelyet egy kitűzött cél, eredmény vagy teljesítmény növelése érdekében végzünk el. A Lean-szemléletű folyamatfejlesztéshez először az alapelveket szükséges megértenünk és implementálnunk a vállalati kultúrába (Womack és Jones, 2003).

A vezérelv az, hogy a termelési folyamat során megtaláljuk, feltérképezzük azokat a tevékenységeket, amelyeket értéket teremtenek, valamint az egyes tevékenységek eredményeként meghatározzuk a termékek értékét. Az értékáramlásnak folyamatosan kell haladnia, húzórendszert kialakítva, a vevői igényeket előtérbe helyezve kell a produktumokat előállítanunk, törekedve a folyamatos fejlődésre, a tökéletességre (Tóth, 2007).

Minöségfejlesztó technikák. Ahhoz, hogy termékeink és szolgáltatásaink a piaci versengésben helyt álljanak és megőrizzük a vevői körünket, esetleg bővítsük azt, valamint az ô igényeiket folyamatosan ki tudjuk elégíteni, nem elegendő csak a termékek tökéletesítésére fókuszálnunk. A kiváló termékek előállításának hátterében nélkülözhetetlen, hogy olyan stabil és hatékony folyamatok és értékáramlás álljon, amelyeket folyamatosan javítunk és fejlesztünk. Ennek elérését segítik a folyamatokat és a minőséget javító eszközök, amelyek alkalmazása a gyakorlati tudást és tapasztalatot társítja a kreativitással (Deming, 2016). 
Ennek megfelelően, hogy folyamatainkat javítani és fejleszteni tudjuk, először azok stabillá tétele szükséges. Ahhoz, hogy ezen fejlesztések kivitelezése milyen mértékben hatásos, olyan módszereket kell alkalmaznunk, amelyek ellenőrizhetők, folyamatos visszajelzést adnak és a vállalati kultúrába építhetôk (Nagy, 2009).

Folyamatsæimuláció. A szimuláció egy valóságon alapuló modell, melynek célja, hogy a folyamatokat, rendszereket és tevékenységeket úgy ábrázoljuk a valóságnak megfelelően, hogy azok áttekinthetők és értelmezhetô legyenek. A folyamatok szimulációját alkalmazhatjuk arra, hogy a lehetséges kimeneteli eredményeket vizsgáljuk meg. $\mathrm{Ha}$ az input, bemenő információink bizonytalanok, esetleg véletlenszerűek, a helyzet szemléltetésére a Monte-Carlo szimulációt alkalmazhatjuk (Pokorádi és Molnár, 2010): „Ha a szimuláció során véletlenül választott pontokat vagy mennyiségeket használunk, akkor Monte-Carlo szimulációról beszélünk”.

\section{A fejlesztés lépései}

A jelen vizsgálatban szereplő üzem hat területi szegmensre bontható: lakkozó-, nyomda- és dobozrészlegen, valamint a COIL tekercsvágó vonalon és EPL (Easy Peel), OT (Open Top) fedélgyártó sorokon történik a termékek előállítása. A kutatást a lakkozó részlegen végeztük, ahol a belső észlelések és a vevői visszajelzések alapján helyeztük fókuszba az egyik gyártósort.

A lakkozási folyamat és az egyes problémák részletesebb vizsgálatához és megértéséhez a „gembán”, az értékteremtés helyén való megfigyelések alapján került elkészítésre a folyamat modellje BPMN 2.0 folyamatábrázolási módszer segítségével (1. ábra).

A lakkozás során előfordulható hibák összegyűjtésével P-FMEA (Process Failure Mode and Effect Analysis) hibamód és hatáselemzés eszköz alkalmazásával vizsgáltuk meg, hogy melyek azok a kritikus pontok vagy rendellenességek, amelyekre kiemelt figyelmet kell fordítani.

1. ábra: A folyamatfejlesztés lépései. Forrás: a Szerzők

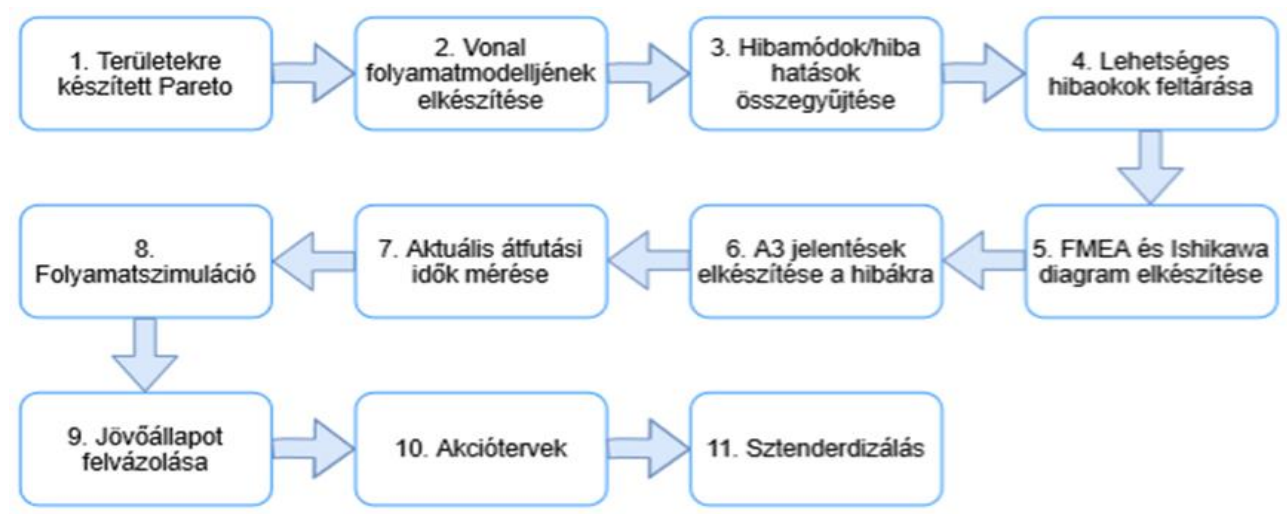


A pontozás alapján négy kritikus probléma került kiválasztásra. A hibákhoz kapcsolódó információk A3 jelentések segítségével lettek összefoglalva, ezek közül egyet analizáltunk tovább

A folyamatmodell kiegészítéseként megtörtént az egyes tevékenységek ciklusidejének mérése és adatbázisban történő összefoglalsa. Ezen adathalmaz segítségével és az egyes javítóintézkedések hatását figyelembe véve készült el a szimuláció, amely a várható értékeket prezentálja.

\section{Eredmények}

A javítóintézkedések és akciótervek megvalósítása után a várható jövőállapoti modellben radikális változás az alapanyagok beszerzésével kapcsolatban képzelhető el. Plusz lehetőségként egy központi raktár létesítése merül fel, amely lehetôvé tenné, hogy a szükséges alapanyagok jelentősen rövidebb átfutási idővel érkezzenek a vállalathoz, valamint a raktározási készleteket és költségeket is csökkenthetőek lennének.

A további intézkedések nem igényelnek nagyobb összegű befektetést, de megvalósításukkal a folyamatok stabilabbak lennének, kevesebb hibázási lehetőséggel és közelebb kerülnénk az elsődleges célunkhoz, az átfutási idő csökkentéséhez, valamint a vevők igényeinek kielégítéséhez.

A szimuláció eredményei. A termelési folyamatmodell szimulációja során három potenciális esetet vettünk figyelembe, és hasonlítottunk össze. Sztenderd értékként megadva a termelés során egy darab termék gyártása tör- ténik, azaz egy raklap, ezerötszáz tábla lemezt tartalmazva. Első lépésként az alapadatok táblája készült el a folyamatmodellek segítségével. Ez az adatbázis lett felhasználva a szimuláció abszolválásához.

Az ideális esetben, azaz amikor komplikáció és szükséges beavatkozás nélkül fut le a folyamat, összesen tizenhárom tevékenység szerepel. A tevékenységek felsorolása során figyelembe vettük, melyek azok, amelyek párhuzamosan is elvégezhetők. A tevékenységek átfutási idejének minimum és maximum értékének meghatározásához, mérési adatbázist készítettünk, az egyes tevékenységek ciklus ideje nyolc alkalommal került lemérésre, ezen adatokat kerültek rögzítésre egy adatbázisban. Következő lépésként a Monte-Carlo szimuláció elméletére alapozva, generált random számok segítségével határoztuk meg a TPT (Total Process Time) teljes átfutási időt. Ezer lefuttatási sor alapján a következő adatok állnak a rendelkezésünkre:

- TPT átlag (min): 102,8247

- Szórás (min): 7,86943

- Megbízhatóság: 0,95

- Várható TPT (min): 115,7687

A jelenlegi, javítandó modell huszonnégy elemből tevődik össze. Ebben az esetben már felvannak tûntetve azok a kritikus pontok, ahol komplikáció léphet fel a folyamat során, valamint az azokra való reagálás, vagyis korrigálás. Ez alapján:

- TPT átlag (min): 931,4386

- Szórás (min): 6,379665

- Megbízhatóság: 0,95

- Várható TPT (min): 941,9322 
A javítóintézkedések megvalósítása utáni, vagyis a jövőállapoti modell, huszonöt tevékenységet tartalmaz. A minimum és maximum értékek, valamint a bekövetkezési valószínűség értékeit realizálható adatokként adtuk meg:

- TPT átlag (min): 396,4268

- Szórás (min): 69,84065

- Megbízhatóság: 0,95

- Várható TPT (min): 511,3044
A 2. és a 3. ábrán látható oszlopdiagramok a három modell adatait hasonlítják össze. A kiemelt adatok és a diagramok alapján megfigyelhető, hogy a javítóintézkedések utáni várt állapot teljes átfutási ideje körülbelül a 47\%-a a jelenlegi állapot várható átfutási idejének. Az ideális, komplikáció nélküli esetben ez az érték 90,75\%.

A szimuláció segítségével reprezentálható, hogy a kritikus pontok feltárásával, és a meg-

2. ábra: Várbató teljes átfutási idők. Forrás: a Szerzőok

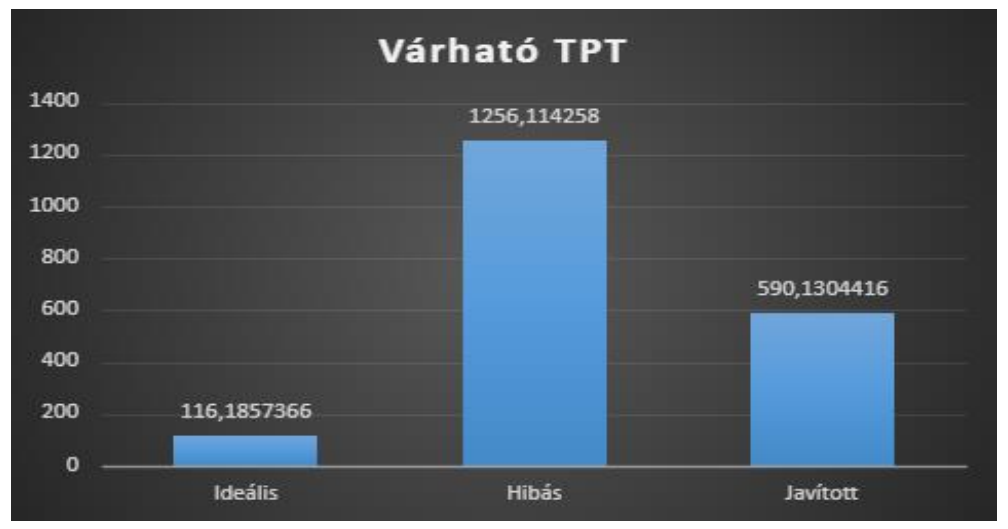

3. ábra: Várbató TPT arányok. Forrás: a Szerzọok

\section{Várható TPT arányok}

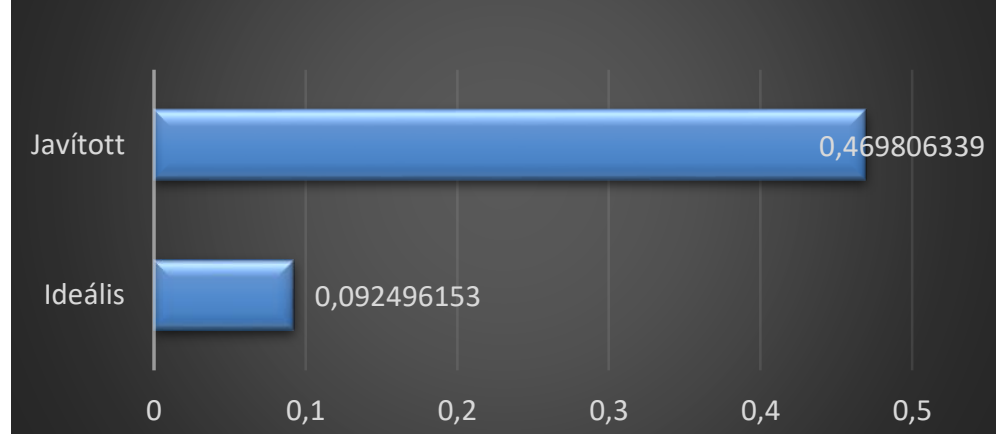


felelő javítóintézkedések meghatározásával és elvégzésével milyen mértékben javulna az átfutási idő. Jelen esetben ez 53\%-os javulást ígér. Ez megfelel a kitűzött célunknak, amelyben elsősorban az átfutási idő csökkentésére fókuszálva, 50\%-os javítási eredményt határoztunk meg.

\section{Konklúzió}

A felhasznált adatok alapján a jelenlegi átfutási idő körülbelül 1256 perc. Ez tízszerese az ideális értéknek. A javító intézkedések megvalósításával a jelenlegi helyzet teljes átfutási ideje a felére csökkenthető.

A meghatározott eredményeken felül az elemzéssel számos előnyre tehet szert a vállalat. A kutatás metódusát más gyártósorain is alkalmazhatja, egyszerűen applikálható. Az egyes javítóintézkedések bevezetése után olyan veszteségeket redukálhat, mint például a selejtszám, készletezési szint, nem szabályozott folyamatok. Tovább fokozhatja és stabilizálhatja piaci helyzetét, akár piaci növekedést és bővebb vevőkört is realizálhat, hiszen megbízhatóbb folyamatokkal és termeléssel partnereik elégedettebbek lehetnek.

Ahhoz, hogy a vállalat és termékei versenyképesek maradjanak és piaci versenyelőnyt élvezzenek, nem elég a termékeket fejlesztenie, a folyamatok fejlesztésére és tökéletesítésére is elegendő energiát kell szánnia. Nem elég az egyes problémákat felszínes, ideiglenes megoldásokkal elhárítani, törekedni kell arra, hogy a kiváltó gyökér okokat felfedjük és megszüntessük. A versenyelőnyhöz gyakran gyors és határozott döntéseket kell meghozni, magas rizikófaktorral, hiszen, ha nem megfelelő adatok alapján döntünk, azok tévútra terelhetnek minket, és nagyobb veszteséget produkálunk, mint fejlődést.

Fontos, hogy ne egyéni gondolatokat erőltessünk a vállalatra: az egyéni és a vállalati céloknak is egyeznie kell. A fejlesztések során vonjuk be támogatókként azokat a team tagokat, akik az aktuális területen érintettek, hogy egymás szakmai tudását és kreativitását kiegészítve határozhassunk meg olyan intézkedéseket és döntési javaslatokat, amelyek a vállat érdekeit szolgáják.

\section{Irodalom}

Deming, W.E. (2016): Quality, Productivity and Cometitive Position MIT Press, Cambridge 1982. American Journal of Industrial and Business Management Vol.6 No.11. november 24, 2016 https://www.scirp.org/pdf/AJIBM_2016 112414424774.pdf

Kósa D. (2020): Monte-Carlo szimulációval támogatott üzleti folyamatfejlesztés. Debreceni Egyetem Tudományos Diákköri dolgozat, Debrecen

Lodgaard, E., Gamme, I. \& Knut. A. (2013): Success Factors for PDCA as Continuous Improvement Method in Product Development. IFIP Advances in Information and Communication Technology. 397. 645-652. 10.1007/978-3-642-40352-1 81

Nagy S. (2009): Folyamat és irányítási rendszer fejlesztése minőségtechnikákkal. Magyar Minőség 2009/11. Letöltés: 2020.09.30. Web:https://quality-mmt.hu/wpcontent/ uploads/2016/06/2009_11MM.pd

Pokorádi L. és Molnár B. (2010): Monte-Carlo szimulációs valószínűségi bizonytalanságelemzés szemléltetése. Repüléstudományi 
közlemények. Letöltés: 2020.10.02. Web: http://www.repulestudomany.hu/kulons zamok/2010_cikkek/Pokoradi_LMolnar_ B.pdf

Tóth Cs. L. (2007): A Lean, ahogyan én látom. Magyar Minóség XVI. évfolyam 2007/8-9 Letöltés: 2020.10.05. Web: https://quality-mmt.hu/wpcontent/uploads/2016/06/mmt beliv 2 00708 09.pdf

Womack, J. P. és Jones, D. (2003): Lean Thinking Free Press. New York: Simon \& Schuster ISBN 0-7432-4927-5 